\title{
O Segredo de Justiça Visto à Luz de uma Justiça Identitária (*)
}

Jorge de Sousa Varela

\section{RESUMO}

O direito à informação é uma das pedras basilares de qualquer democracia moderna. Assim, não só na sociedade em geral mas também na justiça penal em particular, o confronto entre publicidade e segredo deverá terminar, em regra, com a vitória da primeira. Só assim se conseguirá uma justiça menos permeável a abusos de poder e à corrupção que, geralmente, encontram na escuridão do segredo terreno bem mais fértil. Acontece porém que, a bem da eficácia da justiça penal, pode ser necessário manter em segredo o inquérito onde vão sendo reportadas todas as investigações. Ora, durante essa fase do inquérito, o Ministério Público fica em vantagem perante o defensor do arguido que, ao contrário daquele, pode se ver impedido de consultar os autos. Em última instância, pode um arguido estar em prisão preventiva sem que tenha acesso, nem mesmo através do seu advogado, às provas que contra ele existem, colocando em causa o princípio da igualdade de armas processual e a regra da justiça identitária. Não sendo o sistema processual penal português um verdadeiro "processo de partes", tem optado o legislador por salvaguardar tal igualdade de armas impondo ao Ministério Público um dever de objectividade. Resta saber se isso será suficiente.

Palavras-Chave: Segredo de Justiça; Liberdade de Informação; Igualdade de Armas; Justiça Identitária.

\begin{abstract}
The secret of justice in the light of an identity justice

The right to information is one of the cornerstones of any modern democracy. Thus not only in the society in general but also in the criminal justice in particular, the confront between publicity and secret should terminate, as a rule, with the victory of the the first one. Only so a less permeable to abuses justice of power and corruption will be reached. Such permeable justice finds in the darkness of secrecy a far more fertile ground. It happens that, for the sake of the effectiveness of criminal justice, it may be necessary to keep the inquiry, where all investigations are being reported, secret. During this phase of inquiry, the prosecutor has the advantage in comparison to the lawyer of the defendant, who unlike the prosecutor, can be prevented of consulting the lawsuit files. In last instance, a defendant can be under preventive prison with no access, not even through his or her lawyer, to the proof that exists against him or her, putting into question the principle of procedural arms and the rule of identity justice. The Portuguese penal procedural system is not a truly "process of parties", so the legislator has opted to safeguard such equality of arms imposing to the prosecutor a duty of objectivity. The question is whether it will be enough.
\end{abstract}

Keywords: Secret of Justice; Liberty of Information; Equality of Arms; Identity Justice 
- Venha conosco ao juiz, é melhor para todo mundo. Senão, quero lhe avisar lealmente, a história sai todinha amanhã no Diário de Ilhéus. Escrita por mim para você não aparecer como galã. Por mim, João Fulgêncio...

JORGE AMADO, Gabriela, Cravo e Canela

\section{Introdução}

Nem mesmo o mais desatento dos cidadãos poderia ficar imune à autêntica verborreia sobre o segredo de justiça( $\left.{ }^{1}\right)$ que, quase diariamente, encontra tempo de antena nos media nacionais.

Numa democracia que tenta caminhar para uma maioridade, já não apenas cronológica mas intrinsecamente assumida por todos, somos levados a observar que muito caminho se apresenta ainda por percorrer.

À conquista da democracia representativa, na qual se concedeu aos cidadãos o papel de escolher os actores da actividade política e assistir, na qualidade de espectadores, como que ao desenrolar de uma peça de quatro em quatro anos renovada, seguiu-se a democracia participativa. Então, os cidadãos foram convidados a deixar a plateia em direcção ao palco para, conjuntamente com os actores profissionais, participarem no desenrolar desta peça política - no nobre e verdadeiro sentido do termo.

Acontece que o acesso ao palco vem permitindo a cada cidadão, de uma forma desmesurada, e independentemente do guião, escolher as suas próprias deixas. Tal situação, desejável de um ponto de vista dos direitos fundamentais, principalmente quando confrontada com o seu contrário, em que tal direito não exista, não pode deixar de preocupar quem entenda que o direito a ser actor político no palco da sociedade deve ser acompanhado pela responsabilidade de estudar a peça na qual se propõe representar.

* Estudo que corresponde, no essencial, ao relatório apresentado em 02/05/2003 na cadeira de Direito Processual Penal, ministrada pelo Professor Doutor José de Faria Costa, no âmbito do Curso de Mestrado em Ciências JurídicoCriminais pela Faculdade de Direito da Universidade de Coimbra. As principais diferenças devem-se às alterações

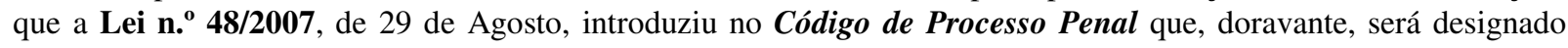
abreviadamente pela sigla $\boldsymbol{C P P}$.

1 Sendo certo que podemos deparar amiúde com o segredo de justiça em vários outros ramos do direito, deve tal instituto ser entendido no âmbito do processo penal quando, doravante, nos referirmos a ele. 
Ora, é isto, nem mais nem menos, o que nos vai sendo dado a assistir nesta acalorada questão do segredo de justiça.

E é também por isto que urge alcançar o próximo estágio da democracia, a democracia cognitiva. Aí, o direito a participar não se esgota em si mesmo. A ausência de censura não implica uma liberdade total. Não enveredando pelo comummente aceite adágio popular de que «a liberdade de um acaba quando a liberdade do outro começa», preferimos acompanhar quem diz que «a liberdade de um vive-se com a liberdade do outro». Pretende- -se, deste modo, deixar claro que o importante já não é cada qual ter o direito ou a liberdade de expressar a sua opinião, mas que, conjuntamente com tal direito, cada cidadão sinta a responsabilidade de pensar, estudar e reflectir nos assuntos sobre os quais se pronuncia para, assim, já não se limitar a dar a sua opinião, mas antes a expor a sua convicção cognitivamente sustentada.

Deste modo, é lançado o desafio aos cidadãos de, uma vez abandonada a plateia e conquistado o palco, possam agora assumir o papel de verdadeiros dramaturgos, responsabilizando-se pelo final da peça. É, pois, numa altura em que todos neste país, independentemente da sua área profissional ou de formação académica, se apressam, quais oráculos, a profetizar grandes reformas alvitrando miraculosas soluções para a suposta crise do segredo de justiça, que, aceitando aquele desafio, vemos aumentada a nossa responsabilidade de, numa forma séria e cientificamente comprometida, escrever sobre o segredo de justiça.

Por tudo isto, optamos propositadamente por ignorar o clarão ofuscante provocado pelos holofotes apontados pela comunicação social que, continuamente, realçam os casos individuais que trazem a debate o segredo de justiça, mas que, tal como a poluição luminosa das cidades não permite que se vejam as estrelas, também o reflexo daqueles holofotes não permite que se enxergue a essência do instituto do segredo de justiça.

Não tendo nós a presunção de que o presente texto possa contribuir, de alguma forma, para a definição daquela essência, não deixaremos de a procurar com a consciência de que, acaso caminhemos no sentido certo, então, ainda que sem a atingirmos, já terá valido a pena.

Partiremos, pois, com a convicção de que tal essência se deverá procurar no final da estrada que nos conduz pelo sentido e pela função do segredo de justiça. Sabendo que o conhecimento destes só poderá ser sustentável pela apreensão dos antecedentes históricos daquele instituto, dedicar-lhes-emos, ainda antes do estudo do sentido e da função do segredo de 
justiça, um capítulo autónomo. Uma vez que a função e o sentido do segredo de justiça estejam teorizados, bem como a forma como, actualmente, a lei no-lo apresenta - e tudo suportado pelos respectivos antecedentes históricos - procuraremos então a sua compatibilização com uma ideia, constitucionalmente arreigada, de justiça identitária.

\section{ANTECEDENTES HISTÓRICOS}

Estando hoje, e na prática, abandonada a construção histórica que se limitava a um desfiar, cronologicamente ordenado, dos factos mais relevantes de um determinado período, podemos encontrar agora novas formas de fazer a história, que chegam a incluir, por exemplo, e por proposta de José Mattoso, o compromisso daquela com o amor.

Não nos aventuramos, até porque não nos reconhecemos qualquer legitimidade para o efeito, na árdua tarefa de, adoptando o método científico próprio à história, construir um verdadeiro documento histórico sobre o segredo de justiça. Ainda assim, e porque advogamos o interesse, ou mesmo a necessidade, de conhecer a evolução dos institutos que nos propomos estudar como forma de melhor podermos compreender a presente solução legislativa encontrada, bem como as actuais questões que sobre eles a doutrina vem levantando, não deixaremos de, sucintamente, apresentar umas breves linhas sobre os antecedentes históricos do segredo de justiça.

Deste modo, e porque esta, apesar de tudo, temerária incursão pelos meandros da história só pode ser entendida como um instrumento facilitador da compreensão do que são as várias perspectivas através das quais o olhar se pode deter sobre o segredo de justiça, será a mesma acompanhada das explanações, agora assumidamente de ordem dogmática, que entendermos necessárias para tal compreensão. Não deixaremos, pois, de englobar nestes antecedentes históricos todos os elementos técnico-jurídicos essenciais para que se perceba todo o desenrolar histórico que, desse modo, sustenta toda esta temática do segredo de justiça.

Necessário se torna, assim, desde logo, mesmo ainda antes do primeiro apontamento de índole histórica, frisar a estreita interligação que se estabelece entre o direito processual penal e o direito constitucional. 


\section{1 - O Direito Constitucional e o Direito Processual Penal}

Entre o direito constitucional e o direito processual penal existe, seguramente, uma hierarquia que, desde logo, garante a superior valência daquele sobre este. No entanto, tais ordenamentos encontram-se como que elasticamente interligados o que, muito embora não obrigue a um equidistanciamento automático, leva a que, de forma mais ou menos próxima, se acompanhem e influenciem reciprocamente. Deste modo, ainda que seja a base a deslocar-se, implica sempre um reposicionamento do topo. Assim, tal relação, se bem que vertical, não pode ser exclusivamente entendida como de supra/infra ordenação mas, antes, numa óptica bidireccional em que ambos se influenciam.

Não sendo este jogo de forças, entre o processo penal e o direito constitucional, um tópico despiciendo para o estudo de qualquer tema relacionado com o direito processual penal, ganha tal relação, quando se fala de segredo de justiça, uma nova dimensão porquanto, como veremos, a relação entre ambos é mais estreita e envolve novos sujeitos.

Com efeito, e como é evidente, cada regime político-constitucional de um qualquer Estado historicamente situado é reflectido na sua constituição ou, se quisermos, na sua Lei Fundamental. Sendo assim, esta é, pois, reveladora daquele regime. Por sua vez, directamente ligado ao regime político-constitucional desse Estado e, consequentemente, em consonância com a sua constituição, encontra-se a estrutura processual penal que nele vigora. Recordemo-nos para já, sem prejuízo de ulterior densificação, apenas dos dois modelos clássicos de processo penal, nomeadamente o acusatório e o inquisitório. Por fim, verdadeiro espelho desta opção entre sistemas processuais penais, vamos encontrar o pendor mais para a publicidade ou mais para o secretismo do próprio processo.

Tudo a conduzir a que a opção entre o secretismo e a publicidade no processo penal seja um dos aspectos centrais para a definição da estrutura ou modelo do próprio processo penal e, assim, devido à estreita ligação deste com a constituição, se constitua como um útil barómetro da estrutura político-constitucional de um Estado.

Útil será também agora, por forma a melhor percebermos o enquadramento daquela opção entre segredo e publicidade, voltarmos então aos sistemas clássicos de processo penal - - o modelo acusatório e o inquisitório -, passando a distingui-los e a situá-los historicamente. 


\section{2 - Os Modelos de Processo Penal Acusatório e Inquisitório}

Desde o momento em que a sociedade se preocupou em fazer penar aqueles seus membros que atentavam contra as regras instituídas, ou, mais correctamente, que cometiam crimes $(2)$, necessário se tornou que houvesse um processo pelo qual se aferisse quem havia sido o autor do crime e em que medida deveria ser punido.

Ao longo dos tempos, e sustentados por ideais diversos, conceberam-se sistemas diferentes para o desenrolar do processo penal.

Cumpre, pois, definir e enquadrar historicamente, se bem que sucintamente, os dois sistemas clássicos de processo penal, o acusatório e o inquisitório, sem esquecermos o mais recente sistema misto.

\section{1 - Modelo acusatório}

$\mathrm{Na}$ estrutura acusatória do processo penal, o arguido, que se presume inocente, é encarado como um sujeito de direitos. Tal presunção de inocência leva a que lhe sejam garantidos os mais amplos meios de defesa. Como forma de assegurar a defesa do arguido, o processo desenrola-se de forma pública e oral, restringindo-se, pois, o segredo de justiça.

Partindo da ideia de que quem investiga e acusa não tem - nem tal lhe poderia ser exigido - a objectividade necessária para julgar o arguido presumindo a sua inocência, o modelo acusatório assenta numa clara separação entre a entidade que acusa e a que julga. Assim, enquanto que à entidade acusadora cabe investigar e acusar, sendo que o arguido tem sempre o direito de conhecer a totalidade dos factos que contra si são imputados, ao julgador fica reservado um papel passivo, limitando-se a observar a contenda entre a acusação e a defesa, para no final ditar a sua decisão. A acusação e a defesa, às quais é garantida uma concreta igualdade de armas, constituem-se como partes processuais, conduzindo a que se observe sempre o contraditório.

2 Cumpre lembrar que nem todos os actos ilícitos, logo atentatórios das regras socialmente instituídas, são crimes. Apenas o são aqueles actos que lesem valores a que a lei atribua tal dignidade. Caso contrário, como acontece as mais das vezes, importarão apenas responsabilidade civil. 


\section{2 - Modelo inquisitório}

Por seu lado, na estrutura inquisitória do processo penal, o arguido não é considerado um sujeito de direitos mas antes como um objecto do processo. Sendo restringidos em larga medida os seus direitos, o arguido é, em regra, privado da liberdade durante o processo. Ao contrário do modelo acusatório, na estrutura inquisitória o julgador não tem um papel passivo, ele é o dominus do processo podendo intervir ex officio.

O processo inquisitório, que aposta mais na eficácia da justiça penal, visa a demonstração e o reconhecimento do poder do Estado e, mais concretamente, do seu soberano, entendendo-se então que a melhor forma de os obter seria através da confissão por parte do arguido. Constitui-se assim, a confissão, como a prova rainha do processo penal, a ponto de poder ser obtida através de tortura.

Por forma a almejar a proclamada eficácia da justiça penal, o processo decorre em segredo, garantindo-se, desse modo, o sucesso das investigações criminais que, uma vez concluídas, e na prática, constituem, as mais das vezes, uma inabalável certeza da culpa do arguido que, não obstante a possibilidade deste se defender na audiência de julgamento, raramente conduzia a outro fim que não o da sua condenação.

Enquanto, portanto, que o modelo acusatório pende para a publicidade, admitindo- -se a possibilidade de limitar, de alguma forma, o sucesso das investigações, por forma a permitir ao arguido evitar a elisão da sua presunção de inocência, no modelo inquisitório a regra é o segredo. Neste só são públicas a sentença e a execução, sendo que, nesta última, a publicitação é levada ao extremo tendo em vista o reforço da autoridade do soberano através do exemplo.

\section{3 - Alternância cronológica}

O facto de o modelo acusatório, tal como sinteticamente o descrevemos, se encontrar mais próximo dos actuais sistemas processuais penais ocidentais, poderia conduzir à ideia de que inicialmente teria existido o modelo inquisitório, assistindo-se posteriormente a uma evolução deste para a actual estrutura acusatória. Muito embora tal erro pudesse encontrar justificação na 
muito nossa tendência de olharmos os fenómenos exclusivamente com os olhos de hoje, cumpre ordenar correctamente a alternância cronológica dos sistemas processuais penais clássicos.

Assim, numa viagem ao longo dos tempos, deparamos primeiro com o sistema acusatório. $\mathrm{Na}$ verdade, o sistema inquisitório representa uma evolução, despojada aqui de qualquer valoração qualitativa, relativamente à estrutura acusatória.

A primeira época em que podemos considerar existir um verdadeiro sistema processual penal remonta à Antiguidade Clássica. Na Grécia e, posteriormente, em Roma, onde ainda vigoravam democracias, o Estado tinha uma autoridade muito limitada. Desconhecida ainda que era a noção de danosidade social do crime, considerava-se o ilícito na perspectiva do interesse privado. Assim, ocorrendo um crime, só o ofendido ou os seus familiares podiam acusar, ficando reservado para o Estado apenas o papel de julgar.

Com o advento do absolutismo, e o consequente reforço do papel do Estado, o crime passou a ser considerado uma ofensa ao poder do soberano. Passou a ter nele incutida a ideia da danosidade social. Deixou, pois, de ser só o ofendido ou familiares a poderem vestir a pele de acusadores podendo, a partir daí, a acusação ser deduzida por qualquer cidadão.( $\left.{ }^{3}\right)$

Tal situação, que rapidamente conduziu a uma multiplicação de acusações, algumas derivadas de interesses ou ódios pessoais, alterou-se com a instituição da figura do acusador como órgão do Estado.

Foi a partir de então que, ao longo da história, as estruturas acusatória e inquisitória do processo penal têm vindo a suceder-se. Se nas Democracias de Roma e Grécia Antigas vigorava, atendendo à separação clara entre acusador e julgador, um modelo do tipo acusatório, com a implantação do poder imperial em Roma, e com o natural fortalecimento da autoridade do Estado, aparece um modelo do tipo inquisitório. Com a queda do Império Romano assiste-se a uma tímida tentativa de repor o sistema acusatório para logo se apagar com o surgimento da Idade Média.

Com o Santo Ofício da Inquisição, que vem a dar o nome à estrutura processual penal, criado em 1215, no $4^{\circ}$. Concílio de Latrão, pelo Papa Inocêncio III, surge o modelo inquisitório em todo o seu esplendor.

3 Sublinhe-se que, neste caso, a dedução da acusação por qualquer cidadão não se limitava à denúncia, cabendo a tal pessoa deduzir e, em julgamento, suportar mesmo a acusação. 
Mais tarde, já no séc. XVIII, através de homens como Montesquieu, Voltaire ou Rousseau, e com o advento da Revolução Francesa, ressurge o sistema acusatório que acaba por não vingar na sua forma pura, uma vez que logo surgiu, muito pela acção do que ficou conhecida como a contra-revolução inquisitória, o sistema misto plasmado no Code d'Instruction Criminelle. O sistema processual penal misto, bebendo dos dois sistemas clássicos, garantia, entre os meios de defesa do arguido, a publicidade e o contraditório durante a fase do julgamento, conservando a instrução do processo sob um manto de secretismo que visava assegurar a eficácia da investigação criminal.

Entre nós, actualmente, é a própria Constituição da República Portuguesa que postula, no $\boldsymbol{n}^{o} .5$ do seu $\boldsymbol{a r t .}^{32^{\circ}}$., que o processo penal tem estrutura acusatória.

\section{SENTIDO E FUNÇÃO DO SEGREDO DE JUSTIÇA}

Tendo ficado definido, necessariamente em traços muito largos, o manto histórico apoiado em ideias chave, estas já com cariz dogmático, como sejam a relação bidireccional, de influência mútua, existente entre o direito constitucional e o processual penal e a possibilidade de se definir um regime político-constitucional como democrático ou ditatorial, respectivamente pelo pendor mais público ou mais secreto do processo penal nele vigente, cumpre, num processo de afunilamento, aproximarmo-nos do instituto do segredo de justiça tentando, desse modo e através da densificação do tema, que será sempre, breviatis causa, pouco profunda, surpreender o seu sentido e a sua função.

\section{1 - O Sentido do Segredo de Justiça}

Sendo que a função do segredo de justiça se prende com o valor que, no nosso ordenamento jurídico-constitucional, é tutelado pela previsão do segredo de justiça, isto é, e afastando-nos da vertente adjectiva do direito penal, convoca o bem jurídico que é defendido pela incriminação da violação do segredo de justiça, vamos encontrar, a montante daquela, o sentido do segredo de justiça que só se pode compreender no confronto com o seu oposto, a liberdade de informação. 


\section{1 - Segredo de justiça Vs. liberdade de informação}

Verificando-se, pois, que a estreita ligação entre o alargamento ou a restrição do segredo de justiça e o regime político-constitucional de um determinado Estado se deve, em primeira linha, à forma como esse Estado considera a liberdade de informação, torna-se necessário, desde logo, como forma de chegar ao conhecimento do sentido do segredo de justiça, compreender a relação entre este segredo e aquela liberdade.

\subsection{1 - A liberdade de informação como regra}

No confronto entre segredo de justiça e liberdade de informação ou, numa linguagem mais plástica, entre opacidade e transparência, verificamos que a opção entre ambos se prende com a promoção de um ideal de justiça penal que cada qual em si contém. É assim que, se, por um lado, os ideais de liberdade, igualdade e fraternidade da Revolução Francesa conduziam a uma ideia de justiça penal assente na presunção de inocência do arguido que, como forma de garantir todos os seus meios de defesa, tornavam o processo num espaço de transparência, logo, impondo a liberdade de informação e a publicidade $\left({ }^{4}\right)$, na Idade Média, por outro lado, apoiados num ideal de que a justiça penal deveria promover a autoridade do soberano, sendo necessário, pois, encontrar sempre o culpado para os crimes que fossem praticados, promovia-se a eficácia das investigações criminais, mais conseguidas, obviamente, ao abrigo do segredo de justiça. Tínhamos, então, o modelo acusatório por um lado, e o modelo inquisitório por outro.

Ora, é deste confronto entre opacidade e transparência, ou segredo e publicidade, que, numa possível concordância prática entre eles, se encontraria, sempre através da opção política, a medida exacta para o segredo de justiça.

Actualmente já não fará sentido encarar a opacidade e a transparência como dois valores absolutos de igual monta. Desde logo, entre nós, a imposição constitucional do modelo acusatório público». Citado por JOSÉ RAIMUNDO GOMES DA CRUZ, "Segredo de Justiça", in Justitia, São Paulo, 42 
do processo penal conduz à prevalência da transparência, da liberdade de informação, durante o processo. Mas mais do que a opção político-constitucional, cumpre realçar - o que poderá mais não ser do que uma evidência - que a liberdade de informação é a regra, é um valor fundamental, apresentando-se a opacidade, o segredo, como o seu limite.

O segredo é, assim, um valor secundário ou instrumental que, muito embora defenda, obviamente, também valores constitucionalmente protegidos, não deixa de ser instrumental.(5) Sem cairmos no extremo, tão vulgarmente pisado hoje em dia, que tenta, por força, fazer crer que a transparência tem que ir conquistando terreno à opacidade até excluir, de todo, o segredo aquilo a que Faria Costa chama de “...obsessão de vitrificação da realidade”( $\left.{ }^{6}\right)$ e que, continua o autor, eleva a transparência à “...imagem mítica da terra abençoada...”(7) -, sem cairmos, então, em tal extremo, assentemos nesse princípio de que a regra fundamental é a da liberdade de informação, da transparência, e o seu limite ou a restrição a essa liberdade, e por isso também a excepção, são os segredos, entre os quais o que agora se trata, o segredo de justiça.

\subsection{2 - Os direitos de informar, de se informar e de ser informado}

Assumindo-se então, o segredo de justiça, como um valor instrumental, como o limite da liberdade de informação, necessário se torna, para que se compreenda o verdadeiro sentido do segredo de justiça, explorar o valor fundamental, ou seja, a própria liberdade de informação.

Cumpre, antes de mais, distinguir, o mais sinteticamente que o rigor científico nos permitir, entre o limite interno e o limite externo que o segredo de justiça impõe à liberdade de informação. Assim, enquanto que o limite externo se estende aos direitos de se informar e de informar por parte de alguém estranho ao processo, no limite interno restringe-se os direitos de se informar e

(110), Jul.-Set. 1980, pág. 155, Apud RICARDO LEITE PINTO, "Direito de Informação e Segredo de Justiça no Direito Português", in Revista da Ordem dos Advogados, Ano 51, Julho 1991, págs. 517 e 518.

5 O segredo ou, como refere JOSÉ DE FARIA COSTA, “...a comunicação fechada é sempre um valor instrumental [...] O que conta, o que é substancial é o fluxo informacional...", in Direito Penal da Comunicação - alguns escritos, Coimbra Editora, 1998, pág. 88.

Op. cit., pág. 96.

7 Op. cit., pág. 95. 
de ser informado por parte de um sujeito processual. $\left({ }^{8}\right)\left({ }^{9}\right)$ Em ambos os limites existe uma restrição ao direito de se informar, o direito que cada um tem de, pelos seus próprios meios, colher informações directamente do processo. No entanto, enquanto que no limite externo, o segredo de justiça restringe o direito de informar sobre o conteúdo do processo por qualquer pessoa estranha ao mesmo, no limite interno, o segredo de justiça restringe o direito do sujeito processual de ser informado.

Para facilitar a exposição, o papel do estranho ao processo, e já que o segredo de justiça lhe restringe o direito de informar, será interpretado por um jornalista, enquanto que o sujeito processual que vê o seu direito de ser informado limitado, e porque nele tal limite assume uma dimensão mais preocupante, será o arguido.

Ora, recordando que a liberdade de informação é a regra e que o segredo de justiça é o seu limite, logo, a excepção, exploremos, como nos propusemos, a liberdade de informação.

Para entendermos na sua plenitude a liberdade de informação e, assim, melhor compreendermos o sentido do seu limite, o segredo de justiça, confrontemos o direito de informar, que atribuímos ao jornalista e que aos jornalistas é obviamente tão caro, servindo até de trave mestra à sua liberdade de imprensa, com o direito, agora do arguido, de ser informado. Do resultado do confronto entre esse direito de informar e este direito de ser informado podemos retirar que o direito de informar não é um direito originário, que valha por si próprio, que se esgote em si mesmo. É um direito secundário que se prende ao direito a ser informado, esse sim, um direito originário.

Deste modo, admitindo que o direito originário não é o direito de informar mas sim o de ser informado, teremos também de concluir que o direito de ser informado não se esgota na simples afirmação do próprio direito. O direito a ser informado só se apresenta na sua plenitude quando se garantir a qualidade da informação. Terá, pois, que ser entendido como o direito a ser bem informado.

Agora, assumindo que da liberdade de informação, consubstanciada como regra, resulta o direito a ser bem informado, podemos dizer que o direito de informar, o direito reclamado pela

8 Assim, embora numa perspectiva da relação entre a justiça e a comunicação social, Cfr. PAULO DÁ MESQUITA, "O Segredo do Inquérito Penal - uma leitura jurídico-constitucional", Direito e Justiça, Vol. XVI, Tomo 2, Universidade Católica Portuguesa, 2000, pág. 50.

9 Sublinhe-se que tais direitos subjectivos inerentes à liberdade de informação - os direitos de informar, de se informar e de ser informado -, estão garantidos ao mais alto nível pelo art. $^{37^{\circ}}$., $\boldsymbol{n}^{\circ} .1$ da Constituição da República Portuguesa. 
comunicação social, se encontra entre aqueles dois. Fica entre o princípio fundamental que garante a liberdade de informação e o direito de ser bem informado que lhe dá sustento filosófico e sociológico, e donde deriva, em termos secundários, o direito de informar.

E é enquanto limite daquela regra, que é a liberdade de informação, sustentada, como vimos, pelo direito de ser bem informado, que o segredo de justiça encontra o seu sentido.

\section{2 - A Função do Segredo de Justiça}

Tratemos agora de encontrar, no nosso ordenamento jurídico, qual o valor tutelado pela previsão do segredo de justiça, isto é, qual a sua função. A busca pela resposta a esta questão leva-nos a sair da vereda pela qual o direito processual nos vinha conduzindo dentro do mais vasto domínio do direito penal. Encontrar a função desse instituto do direito penal adjectivo, que é o segredo de justiça, equivale a encontrar, agora já no direito penal objectivo, o bem jurídico que é defendido pela incriminação da violação do segredo de justiça.

Limitando valores como o da liberdade de informação, o segredo de justiça, como, aliás, qualquer outro segredo, só pode ser pensado se através dele se conseguirem proteger outros interesses ou valores. Quais, então, esses valores?

Numa primeira tentativa, pouco cuidada, de encontrar a função do segredo de justiça, poder-se-ia pensar que este visasse acautelar a presunção de inocência do arguido, uma vez que a divulgação dos actos processuais conduziriam ao chamado public trial, podendo acarretar, desde logo, a condenação pública do arguido.

Carece, no entanto, tal raciocínio de exactidão. Por um lado, dificilmente se pode aceitar que o segredo de justiça seja constituído a favor do arguido uma vez que, restringindo-lhe o acesso ao processo, ele é efectivamente limitativo dos seus direitos de defesa. Por outro lado, se o segredo de justiça existisse para proteger a presunção da sua inocência, o arguido teria sempre o direito a abdicar dele, o que, obviamente, não acontece.(10) Por fim, admitir que a presunção de inocência do arguido pudesse ser afectada pela publicidade, implicaria a manutenção do segredo

10 Muito embora a recente alteração ao $\boldsymbol{C P P}$ permita ao arguido requer o levantamento do segredo de justiça, não só tal direito não é exclusivo do arguido, que o partilha com o assistente e com o ofendido, como o Ministério Público pode não o aceitar, remetendo assim a decisão para o Juiz de Instrução, conforme disposto no $\boldsymbol{a r t .} 8 \boldsymbol{8 6}^{\boldsymbol{o}}$., $\boldsymbol{n}^{\boldsymbol{o}}$.s $4 \boldsymbol{e} \mathbf{5}$ do $\boldsymbol{C P P}$. 
de justiça enquanto aquela durasse, ou seja, até ao trânsito em julgado de uma sentença condenatória.

Também chegou a ser proclamada, como um dos valores que o segredo de justiça visava proteger, a independência do julgador, só concebível com a serenidade e a tranquilidade proporcionadas pelo segredo que impediria quaisquer intromissões de terceiros ou influências variadas.

Cremos que não será também esta a resposta mais acertada. Julgamos que o segredo de justiça não tem como função salvaguardar a independência do julgador. Isto porque o acto judicativo é, por norma, público. Ora, não se vê de que modo é que a divulgação de actos, ou respectivos conteúdos, que já são normalmente públicos possa prejudicar, seja em que medida for, a independência de quem os tutela. Diz-nos, por outro lado, a experiência que a publicidade garante melhor a independência do acto judicativo do que o segredo. Sem cairmos no exagero da famosa frase do marquês de Mirabeau, já antes citada, podemos concordar, sem mais, que o segredo é terreno mais fértil para o aparecimento de situações menos claras, propiciadoras da indesejada parcialidade.

Apontada também, como uma das funções do segredo de justiça, costuma ser a protecção da reserva de vida privada e da honra das pessoas envolvidas.

Aqui, reconheçamos, o segredo de justiça assegura efectivamente também essa protecção. Certos pontos do seu regime, inclusivamente, visam exactamente essa protecção.(11) No entanto, somos levados a concluir não ser essa a principal razão da existência do segredo de justiça. Isto porque, por um lado, o segredo de justiça estende-se a actos processuais que em nada colidem com a vida privada ou com a honra, por outro, o eventual consentimento da pessoa lesada não exclui a punição de quem violar o segredo de justiça.

No entanto, a recente alteração introduzida no $\boldsymbol{C P P}$ vem dar corpo a esta solução. Ao permitir, no $n^{o} .2$ do $\operatorname{art} 86^{\circ}$, que o segredo de justiça seja aplicado ao processo, a requerimento do arguido, do assistente ou do ofendido, quando o Juiz de Instrução entenda que a publicidade prejudica os direitos daqueles, o legislador admitiu que o segredo de justiça deve também servir

11 Considere-se, por exemplo, o caso de vítimas de crimes contra a liberdade e autodeterminação sexual. Cfr. $\boldsymbol{a r t . ~} 87^{\circ}$, $n^{o} .3$ do $\boldsymbol{C P P}$. 
para protecção de direitos individuais dos cidadãos. Como adiante veremos, parece-nos uma admissão arriscada.

Qual então a principal função do Segredo de Justiça?

Temos para nós, como de certo modo já antes havíamos deixado advinhar, que a principal função do segredo de justiça decorre da necessidade de se conferir eficácia à justiça penal. Visa, assim, acautelar o risco de perturbação das diligências probatórias e de investigação que poderiam, em última análise, levar o arguido a subtrair-se à acção da Justiça. Com efeito, se o arguido tivesse conhecimento das diligências investigatórias em curso, poderia impossibilitar o seu sucesso. Basta pensarmos nas actualmente tão polémicas escutas telefónicas.

\section{O SEGREDO DE JUSTIÇA POSITIVADO EM LEI}

Muito embora houvéssemos pensado este trabalho mais na procura do que é, dogmaticamente, o instituto do segredo de justiça, retirado do estado em que circunstancialmente está assente na lei, tentando surpreender, desse modo, o seu sentido e a sua função, não consideramos obviamente despiciendo o estudo da solução que, actualmente, o nosso legislador encontrou para definir o segredo de justiça.

Parecendo, pois, ab initio, poder relegar-se para segundo plano o exame do segredo de justiça positivado em lei, uma vez que nos preocuparia mais o levantamento de algumas questões controversas na doutrina e a consequente reflexão sobre elas, seria sempre necessário recordá-lo para, ancorados na legislação, procurarmos dar resposta à questão, porventura a decisiva deste estudo, da intrincada conformação do segredo de justiça, como actualmente o nosso legislador o concebe, com uma ideia de justiça identitária.

Ainda assim, diremos que o estudo do segredo de justiça positivado no Código de Processo Penal, sem esquecer a protecção que, desde a revisão de 1997, a Constituição da República Portuguesa lhe dispensa, será tão minucioso quanto necessário e tão sintético quanto possível.

Recordando que a publicidade, a transparência, é, até pela imposição constitucional da estrutura acusatória do processo penal, a regra, vamos perceber como a legislação ordinária vai conformar essa estrutura acusatória com o princípio da investigação, retirando ao julgador um 
papel passivo. Criou-se, assim, um processo com uma fase inicial, de investigação, onde impera o segredo de justiça, garantindo ulteriormente, para a fase do julgamento, a publicidade.

É, pois, o estudo do segredo que acompanha essa primeira fase do processo penal e que restringe a liberdade de informação, não só para fora mas também para dentro do próprio processo, que, nas suas vertentes objectiva, subjectiva e temporal de vigência, nos ocupará as próximas linhas.

\section{1 - Âmbito Objectivo do Segredo de Justiça}

Discorrer sobre o âmbito objectivo do segredo de justiça leva-nos a indagar sobre quais as concretas proibições que, em face do segredo, se opõem a quem pretendesse usufruir da liberdade de informação que, caso aquele não existisse, abriria o processo de par em par.

Assim, e muito sucintamente, podemos retirar do conteúdo das alíneas a) e $\boldsymbol{b}$ ) do $\boldsymbol{n}^{\boldsymbol{o}} . \mathbf{8}$ do $\boldsymbol{a r t .} \mathbf{8 6 ^ { \boldsymbol { o } }}$. do $\boldsymbol{C P P}$ uma dupla proibição, que a todos vincula, nomeadamente de assistência à prática ou tomada de conhecimento do conteúdo de acto processual a que não tenham o direito ou o dever de assistir (al. a)), e de divulgação da ocorrência de acto processual ou dos seus termos, independentemente do motivo que presidir a tal divulgação $(\boldsymbol{a l} . \boldsymbol{b}))$.

No tocante à proibição plasmada na alínea $a$ ), cumpre compatibilizar o seu conteúdo com o da alínea a) do $\boldsymbol{n}^{\boldsymbol{o}} .1$ do $\mathbf{a r t .} \mathbf{6 1}^{\boldsymbol{o}}$. do $\boldsymbol{C P P}$, realçando que ao arguido é permitido estar presente aos actos processuais que directamente lhe disserem respeito.

Quanto à proibição da alínea b), refira-se que só esta encontra paralelo na lei substantiva, porquanto o assistir ou o tomar conhecimento, se bem que ilegitimamente, de conteúdo de acto processual, não se insere, claramente, na conduta típica prevista na incriminação do $\mathbf{a r t} \cdot \mathbf{3 7 1 ^ { \boldsymbol { o } }}$. do Código Penal. Para o preenchimento de qualquer das formas da conduta típica daquele preceito normativo, seria sempre necessário a divulgação ilegítima do teor de acto processual. A assistência ou a tomada de conhecimento ilegítimas do conteúdo de um acto processual apenas implicam, por força do disposto no $\boldsymbol{n}^{\circ} .8$ do $\operatorname{art.~}^{86^{\circ}}$. do $\boldsymbol{C P P}$, que a pessoa que assistiu ou tomou conhecimento passa, também ela, a estar vinculada ao segredo de justiça.

\section{2 - Âmbito Subjectivo do Segredo de Justiça}


No que toca ao âmbito subjectivo do segredo de justiça, ou seja, às pessoas a que o segredo se impõe, importa referir que a lei o previu na sua maior extensão. Tanto assim é que o $\boldsymbol{n}^{o} .8$ do art. $86^{\circ}$. do $\boldsymbol{C P P}$ estipula que o segredo de justiça vincula todos os sujeitos $e$ participantes processuais, optando assim expressamente por não se limitar aos sujeitos processuais $\left({ }^{12}\right)$, abrangendo igualmente todos aqueles que, de algum modo, se relacionem com o processo.

Acresce que o mesmo dispositivo legal refere ainda que, para além dos sujeitos $e$ participantes processuais, ficam igualmente vinculadas pelo segredo de justiça todas as pessoas que, por qualquer título, tiverem tomado contacto com o processo e conhecimento de elementos a ele pertencente.

De realçar que, à cautela, veio ainda o legislador, no $\boldsymbol{n}^{\circ} .10$ do $\operatorname{art.~}_{\mathbf{8 6}}$. do $\boldsymbol{C P P}$, porventura redundantemente - em face da abrangência genérica do $\boldsymbol{n}^{\boldsymbol{o}} .8$-, vincular ao segredo todos aqueles a que, ao abrigo do $\boldsymbol{n}^{\boldsymbol{o}} \mathbf{9}$ do mesmo artigo, a autoridade judiciária houvesse dado conhecimento do conteúdo de actos processuais.

\section{3 - Âmbito Temporal de Vigência do Segredo de Justiça}

Mantendo o enfoque na publicidade enquanto regra do processo penal, a actual versão do $\boldsymbol{C P P}\left({ }^{13}\right)$ deixa claro, no $\boldsymbol{n}^{\circ} .1$ do seu art. $\mathbf{8 6}^{\circ}$., que ressalvadas as excepções previstas na lei, o processo penal é, sob pena de nulidade, público. Dos $\boldsymbol{n}^{\circ}$.s 2 e 3 do mesmo art. $86^{\circ}$., resulta claramente que, caso não exista interesse no segredo por parte do arguido, do assistente, do ofendido ou do Ministério Público, o processo pode decorrer integralmente em publicidade. Caso exista esse interesse, o segredo parece resumir-se, salvo as devidas excepções, à fase do inquérito, conforme resulta dos referidos $n^{o} . s 2$ e 3 .

Antes desta última alteração ao $\boldsymbol{C P P}$, a obrigação da publicidade começava apenas a partir da decisão instrutória ou, se a instrução não tivesse lugar, do momento em que já não poderia ser requerida, sendo que havia ainda a possibilidade de o segredo cessar a partir do recebimento do

12 Previstos e assim intitulados no Livro I da Parte Primeira do $\boldsymbol{C P P}$. 
requerimento da abertura da instrução, se esta fosse requerida apenas pelo arguido e este, no requerimento, não declarasse que se opunha à publicidade. Tudo a conduzir à conclusão, através de uma interpretação a contrario, de que até àquele momento vigoraria sempre o segredo de justiça. O facto do anterior $\boldsymbol{n}^{\boldsymbol{o}} .1$ do $\operatorname{art} .86^{\boldsymbol{o}}$. do $\boldsymbol{C P P}$ criar um instrumento para dispor sobre a manutenção ou a cessação da vigência do segredo de Justiça e, principalmente, o deixar apenas nas mãos do arguido, potenciou várias críticas, embora, a nosso ver, nem sempre acertadas.

A crítica que Maia Gonçalves apresentava no sentido de que com este regime se estaria a violar o princípio da igualdade de armas, $\left({ }^{14}\right)$ deve-se, na nossa opinião, a uma menos conseguida interpretação daquele princípio da igualdade de armas que, como adiante veremos, não é caso isolado. Inclusivamente, ao escrever que, "Na realidade, o assistente pode ter um interesse tão atendível como o do arguido na manutenção do segredo de justiça durante a instrução.”(15), já passou Maia Gonçalves, no nosso entendimento, a laborar em erro de raciocínio. Com efeito, ao requerer a abertura da instrução, o assistente, ou porque o inquérito havia sido arquivado ou porque a acusação não continha todos os factos, tem sempre em vista a realização do julgamento do arguido que é, até por força constitucional, público. Logo, ao requerer a abertura da instrução, não se vislumbra a possibilidade de o assistente desejar manter o processo em segredo de justiça uma vez que o que ele pretende, como vimos, é que o processo avance para uma fase em que a publicidade é a regra. Na verdade, o único sujeito processual que teria, em regra, interesse em que o processo acabasse antes mesmo de terminar o segredo, nomeadamente o segredo externo, era o arguido. Daí que se compreendesse, neste âmbito, uma vez que o legislador parecia não querer admitir a possibilidade de terminar o segredo interno independentemente do segredo externo, a opção legislativa que oferecia apenas ao arguido a faculdade de terminar o segredo.

Mais fundamentada, no entanto, parece ser a crítica que Laborinho Lúcio(16) fazia a este aditamento ao anterior $\boldsymbol{n}^{\boldsymbol{o}} . \mathbf{1}$ do $\mathbf{a r t} . \mathbf{8 6}^{\boldsymbol{o}}$. do $\boldsymbol{C P P}$, operado em 1998, especialmente quando confrontado com a alteração constitucional do ano anterior. Com efeito, o segredo de justiça

13 Mais em consonância, aliás, com a imposição da estrutura acusatória do processo penal prevista no $\boldsymbol{n}^{\boldsymbol{o}} .5$ do $\boldsymbol{a r t .} 32^{\boldsymbol{o}}$. da Constituição da República Portuguesa.

14 In Código de Processo Penal - anotado e comentado, 11ª . Ed., Almedina, 1999, pág. 245.

15 Op. cit., pág. 245.

16 Vide “A Reforma do Processo Penal: O que ficou por rever?", in O Processo Penal em Revisão - comunicações, $1^{\mathrm{a}}$. Ed., Universidade Autónoma de Lisboa, 1998, págs. 201 a 205. 
atinge, com a Lei Constitucional $n^{o}$. 1/97 de 20 de Setembro, dimensão constitucional, integrando o art. $20^{o}$., $n^{o} .3$ da Constituição da República Portuguesa, o qual postula que a lei define e assegura a adequada protecção ao segredo de justiça.

Ora, uma vez definido que foi que o segredo de justiça tem por função proteger, em nome da justiça, a eficácia das investigações e não ser um garante de interesses individuais do arguido, mal se compreendia, na senda de Laborinho Lúcio, como se poderia compatibilizar a constitucionalização do segredo de justiça com o deixar na disponibilidade do arguido a manutenção do segredo durante a fase da instrução. A não ser que, de uma vez por todas, se admitisse uma dupla função do segredo de justiça: a de protecção da eficácia da investigação e a de “...tutela [...] de valores tributários de direitos individuais fundamentais do cidadão arguido;"(17). Ora, como vimos, o legislador veio recentemente admitir tal dupla função. Julgamos, todavia, que o assumir desta dupla função do segredo de justiça acarreta o risco de conduzir, em breve trecho, à situação em que não mais se procura tutelar os «direitos individuais fundamentais dos cidadãos» mas antes os «direitos individuais dos cidadãos fundamentais».

Quanto ao momento a partir do qual o processo penal se deve considerar ao abrigo do segredo de justiça, a recente alteração do $\boldsymbol{C P P}$ vem clarificar a situação. Será a partir do momento em que, $a$ requerimento do arguido, do assistente ou do ofendido, o Juiz de Instrução o determinar, conforme o $\boldsymbol{n}^{o} .2$ do art. $86^{\circ}$. do $\boldsymbol{C P P}$, ou quando o Ministério Público entender que os interesses da investigação ou os direitos dos sujeitos processuais o justifiquem, conforme o $\boldsymbol{n}^{\boldsymbol{o}} \mathbf{. 3}$ do mesmo artigo. Na versão anterior do $\boldsymbol{C P P}$, a interpretação a contrário que se fazia do $\boldsymbol{n}^{\boldsymbol{o}} \mathbf{1}$ do $\boldsymbol{a r t} \mathbf{8 6 ^ { \boldsymbol { o } }}$. levava à conclusão que a obrigação de segredo começava com o início do processo, ou seja, com o despacho que ordena a abertura do inquérito. No entanto, facilmente se compreendia que determinados actos prévios a tal despacho, como sejam as providências cautelares a praticar pelos órgãos de polícia criminal $\left({ }^{18}\right)$, se deviam, também elas, considerar sob a obrigação de segredo.(19) Actualmente, tal afirmação pode ficar prejudicada pelo facto de, em ambas as situações que podem levar à aplicação ao processo do segredo de justiça, que se encontram nos

17 Op. cit., pág. 204.

18 Previstas no art. $^{249^{\circ}}$. do $\boldsymbol{C P P}$.

19 Assim, MEDINA DE SEIÇA, comentário ao art. 371 ${ }^{\text {. }}$. do Código Penal - violação de segredo de justiça, in Comentário Conimbricense do Código Penal - parte especial, Tomo III, Coimbra Editora, 2001, pág. 649. 
referidos $\boldsymbol{n}^{o}$.s 2 e 3 do $\boldsymbol{a r t} .86^{\circ}$. do $\boldsymbol{C P P}$, se deixar claro que tal apenas acontece durante a fase de inquérito.

\section{O SEGREDO DE JUSTIÇA E A IGUALDADE DE ARMAS}

Encontrando-se, então, praticamente definido o quadro geral do instituto jurídico do segredo de justiça no processo penal, nomeadamente quanto ao seu sentido, à sua função e, muito sinteticamente, à sua concretização legal, resta responder à questão, que nos vem acompanhando desde o início deste estudo, sobre a compatibilização do segredo de justiça, positivado em lei, com uma ideia de justiça identitária suportada constitucionalmente.

Vimos que o processo penal tem, por força da constituição, uma estrutura acusatória. Apercebemo-nos também que não se trata de um modelo acusatório puro, encontrando-se corrigido pelo princípio da investigação. Ao invés do sistema acusatório puro, o julgador não assume, no processo penal em Portugal, um papel passivo podendo procurar oficiosamente a verdade material. Ao contrário também do sistema acusatório puro, no nosso processo penal pode existir uma fase inicial não pública, onde a regra é o segredo. Compreendemos que tal secretismo não se deve à protecção da presunção de inocência do arguido, nem tão pouco visa salvaguardar a independência do julgador. Muito embora o legislador tenha vindo recentemente a admitir que o segredo de justiça também serve para proteger a reserva de vida privada e a honra dos intervenientes no processo, deixámos a nossa convicção de que não será esse o seu principal fito. A existência do segredo de justiça no processo penal deve-se primeiramente, isso sim, à necessidade de garantir o sucesso das investigações criminais e, consequentemente, a eficácia da justiça penal. É, no fundo, um instrumento ao dispor do investigador/acusador.

Ora, é aqui que, numa primeira leitura, surge a dúvida sobre a possibilidade de fazer coabitar este segredo de justiça, tal qual o descrevemos, com a suposta justiça identitária. Será que uma tão poderosa ajuda ao serviço do acusador não inviabilizará a igualdade de armas? Será que uma estrutura processual penal que proclama a igualdade de armas pode permitir que uma pessoa seja investigada, constituída como arguido, por vezes sujeita a prisão preventiva, e durante toda a investigação não saber quais as provas, quais os indícios, que o órgão acusador tem contra si? 
Na busca pela solução deste aparente paradoxo, vamos perceber que a coerência interna que, apesar de tudo, se pode surpreender em toda esta trama que traçámos, assenta em três tópicos.

Em primeiro lugar o suposto favorecimento do acusador, do Ministério Público, relativamente ao arguido é compensado, pelo menos em teoria, pela obrigação que impende sobre aquele de se reger por critérios de estrita objectividade.(20) O magistrado do Ministério Público deve, no decorrer de todo o processo penal, procurar atingir a verdade material, inclusivamente pugnando, se for caso disso, pela absolvição do arguido.

Deste primeiro tópico podemos partir de imediato para o segundo, que decorre directamente daquele, para concluir que o processo penal não é um processo de partes. Acima de tudo, a acusação busca uma decisão justa. Não estando o Ministério Público interessado, tout cour, na condenação do arguido, não se deve verificar, mais uma vez atendendo unicamente à pureza da lei, um litígio entre acusação e defesa.

O terceiro e último tópico, no qual nos deteremos um pouco mais, assenta na verdadeira interpretação que deve ser dada ao princípio da igualdade de armas entre a acusação e a defesa no julgamento penal.

Desde logo, cumpre esclarecer que entre nós, como, aliás, na grande maioria dos países europeus, a doutrina e a jurisprudência vem encontrando o suporte do princípio da igualdade de armas, e, assim, o fundamento para a sua vigência no nosso direito interno, no disposto no $\operatorname{art.~}^{\boldsymbol{o}} . \boldsymbol{n}^{\boldsymbol{o}} .1$ da

\section{Convenção Europeia dos Direitos do Homem.}

O já referido paradoxo resultante da simultânea vigência do segredo de justiça e do princípio da igualdade de armas, deriva, como já antes adiantámos, de um menos correcto entendimento que deste, amiúde, se faz. Não pode tal princípio, como bem refere Figueiredo Dias, “...ser entendido como obrigando ao estabelecimento de uma igualdade matemática ou sequer lógica...”(21) entre a acusação e a defesa. Se assim acontecesse, tornar-se-iam inviáveis muitos princípios do processo penal, alguns com protecção constitucional, as mais das vezes favoráveis ao próprio arguido, como por exemplo a presunção da sua inocência, o in dubio pro

20 Cfr. $\operatorname{art.}^{53^{\circ}}$, $\boldsymbol{n}^{o} .1$, in fine, do CPP.

21 In "Sobre os Sujeitos Processuais no Novo Código de Processo Penal", Jornadas de Direito Processual Penal - O Novo Código de Processo Penal, CEJ, Livraria Almedina, 1988, pág. 29. 
reo, ou mesmo o direito do arguido ao silêncio que, claramente, atentam contra uma hipotética igualdade de armas entendida como igualdade absoluta entre defesa e acusação.

Acresce que, se o princípio da igualdade de armas devesse ser interpretado como garantindo uma igualdade matemática entre acusação e defesa, ter-se-ia que desobrigar o ministério público do seu dever de objectividade, ou, então, obrigar o arguido ao mesmo.

A vigente igualdade de armas, que deve continuar a ser defendida, só poderá ser correctamente entendida “...quando lançada no contexto mais amplo da estrutura lógicomaterial global da acusação e da defesa e da sua dialéctica.”(22). Com efeito, deste modo apenas deverá ser considerada como violadora do princípio da igualdade de armas, agora já correctamente entendido, a opção processual que se deva considerar “...infundamentada, desrazoável ou arbitrária; como ainda quando possa reputar-se substancialmente discriminatória à luz das finalidades do processo penal, do programa político-criminal que àquele está assinado ou dos referentes axiológicos que o comandam.”(23).

\section{CONSIDERAÇÕES FINAIS}

Procurámos um caminho que nos levasse na direcção da essência do instituto do segredo de justiça no processo penal. Uma vez abastecidos da informação necessária recolhida nos seus antecedentes históricos, enveredámos por aquele que nos fizesse parar um pouco no sentido e na função do segredo de justiça.

A propositada exiguidade do presente estudo não permitiu que nos detivéssemos muito em cada uma daquelas paragens. Vimos, todavia, como o segredo de justiça encontra o seu sentido no limite em que se consubstancia face à liberdade de informação, essa sim, o valor fundamental, da qual resulta, em primeira linha, o direito a ser bem informado e, a título secundário, o direito de informar; e concluímos que o segredo de justiça tem por função principal acautelar a eficácia da justiça penal, prevenindo, desse modo, os riscos de perturbação das diligências probatórias e das investigação criminais, evitando assim que o arguido se subtraia à acção da Justiça. Paralelamente a esta, quis o legislador atribuir ao segredo de justiça a função de

22 In FIGUEIREDO DIAS, Op. cit., pág. 30.

23 In FIGUEIREDO DIAS, $O$ p. cit., pág. 30. 
protector dos direitos individuais dos participantes processuais. Em tempo apresentámos as nossas reservas a esta opção.

Deste modo, o segredo de justiça surge-nos como a afirmação do compromisso entre a garantia dos meios de defesa do arguido, com a consequente facilitação do acesso pelo mesmo aos autos, e a promoção da eficácia das investigações criminais e das diligências probatórias, o que, por seu lado, apela à restrição do acesso por parte do arguido, bem como de terceiros, ao processo. Tal compromisso entre liberdade de informação e eficácia das investigações mais não é do que “...o equilíbrio instável entre opacidade e transparência...”, cuja gestão, são palavras de Faria Costa, “...é tarefa da comunidade organizada em poder político a que o direito penal pode emprestar o seu contributo."(24).

Tudo a conduzir a que a regra fundamental seja, então, a de que deva haver tanto segredo quanto for necessário e tanta liberdade de informação quanto possível.

Deparámos, contudo, com um obstáculo no nosso percurso.

Concebido o segredo de justiça como uma arma ao serviço da justiça - é inegável a absoluta necessidade do segredo de justiça durante as investigações criminais, bem como o proveito que dele retira, para a sua acção, o Ministério Público -, facilmente nos apercebemos do potencial inquisitório que este instituto agrega. Muito embora a lei tente evitar, como vimos, a tal suposta desigualdade de armas, com a imposição ao Ministério Público de obedecer a critérios de estrita objectividade, cada vez mais são os que denunciam a incapacidade prática de todos os titulares daquela magistratura autónoma de se manterem impenetráveis à tentação de deixarem de ser o sujeito processual que deduz e sustenta a acusação para se assumirem como a parte acusadora.

Ficamos assim em face dum confronto entre, por um lado, a eventual necessidade da vigência do segredo de justiça durante as diligências investigatórias e, por outro, a sempre presente possibilidade de que uma humana desobediência àqueles critérios de estrita objectividade rapidamente se possa transformar numa concreta violação ao princípio da igualdade de armas com óbvios e graves prejuízos para o arguido.

Por tudo isto, ousamos expor a nossa convicção de que, ao invés de tentar encontrar soluções, como a sujeição do Ministério Público a critérios de objectividade, que o levem a não

24 Op. cit., pág. 96. 
utilizar o segredo de justiça como uma arma desigual, deveria o legislador preocupar-se em limitar os efeitos nefastos que da inevitável utilização daquela arma - errare humanum est possam advir para o arguido.

Neste sentido, admitindo-se que, para o arguido, a mais prejudicial característica dos efeitos nefastos do segredo de justiça se reporta, mais do que aos efeitos em si, ao seu excessivo prolongamento no tempo, porventura melhor opção legislativa seria restringir a extensão temporal da sua vigência para períodos aceitáveis. Não mais se assistiria, desse modo, às actuais situações pouco compatíveis, diga-se, com a estrutura acusatória imposta constitucionalmente -, em que um arguido, eventualmente sujeito à medida de coacção de prisão preventiva, é mantido na ignorância, por vezes durante meses, sobre as provas concretas que contra ele existem.(25) A profunda revisão a que o $\boldsymbol{C P P}$ foi sujeito foi, neste âmbito, uma oportunidade perdida.

Sublinhando a pertinência actual do segredo de justiça no processo penal, concluiremos, pois, este nosso trabalho com uma porventura atrevida apropriação de uma interrogação, na qual deixámos intactos o seu aroma irónico e o seu sentido provocatório e que, por isso mesmo, a deixaremos irrespondida. Assim, com Faria Costa, questionamo-nos: "Se se propugna uma sociedade aberta à informação, a toda a informação, que sentido tem continuar a falar-se de segredo e de sigilo?"(26).

\section{REFERÊNCIAS BIBLIOGRÁFICAS}

BELEZA, Teresa Pizarro. Direito Penal, 2 vols., AAFDL - 1985, Lisboa.

COSTA, José Francisco de Faria.Direito Penal da Comunicação (alguns escritos), Coimbra Editora - 1998, Coimbra.

DIAS, Jorge de Figueiredo. Sobre os Sujeitos Processuais no Novo Código de Processo Penal, in Jornadas de Direito Processual Penal - O Novo Código de Processo Penal, CEJ, Livraria Almedina - 1988, Coimbra.

ESTEVES, Maria da Assunção A. A Jurisprudência do Tribunal Constitucional Relativa ao Segredo de Justiça, in Estudos de Direito Constitucional, Coimbra Editora - 2001, Coimbra.

25 Mesmo não ultrapassando os prazos máximos estipulados na lei, é possível que um arguido em prisão preventiva veja o seu acesso ao processo negado pelo segredo de justiça durante um ano. Cfr. arts. $\mathbf{2 7 6}^{\boldsymbol{o}}$. do $\boldsymbol{C P P}$.

26 op. cit., pág. 84. 
FERREIRA, Manuel Cavaleiro de. Direito Penal Português, 2 vols., Editorial Verbo - 1982, Lisboa.

GONÇALVES, Manuel Lopes Maia. Código de Processo Penal - anotado e comentado, 11ª. Ed., Almedina - 1999, Coimbra.

LÚCIO, Álvaro Laborinho. A Reforma do Processo Penal: O que ficou por rever?, in O Processo Penal em Revisão - comunicações, $1^{\text {a }}$. Ed., Universidade Autónoma de Lisboa - 1998, Lisboa.

MESQUITA, Paulo Dá.O Segredo do Inquérito Penal - uma leitura jurídico constitucional, in Direito e Justiça, Vol. XVI, Tomo 2, Universidade Católica Portuguesa - 2000, Lisboa.

MONTE, Mário Ferreira. O Segredo de Justiça na Revisão do Código de Processo Penal: principais repercussões na comunicação social, in Scientia Iuridica, T. XLVIII, $\mathrm{n}^{\circ} . \mathrm{s}$ 280/282 1999, Braga.

PINTO, Ricardo Leite. Direito de Informação e Segredo de Justiça no Direito Português, in Revista da Ordem dos Advogados, Ano 51 - Julho 1991, Lisboa.

SANTOS, Manuel Simas; LEAL- HENRIQUES, Manuel \& PINHO, David Broges de. Código de Processo Penal - anotado, 2 vols., Rei dos Livros - 1996, Lisboa.

SEIÇA, A. Medina de. Artigo $371^{\circ}$ (Violação de segredo de justiça), in Comentário Conimbricense do Código Penal - Parte Especial, T. III, Coimbra Editora - 2001, Coimbra.

SILVA, Germano Marques da. Curso de Processo Penal, 3 vols., Editorial Verbo - 1993, Lisboa. TEIXEIRA, Sálvio de Figueiredo. A Imprensa e o Judiciário, in Scientia Iuridica, T. XLVIII, $\mathrm{n}^{\circ} . \mathrm{s}$ 280/282 - 1999, Braga. 